\title{
Assessment of Safety Performance in Banana Alcoholic Beverage Processing Factories in Rwanda
}

\author{
Grace Irakiza ${ }^{1}$, Viateur Ugirinshuti ${ }^{2}$, Olivier Kamana ${ }^{2} \&$ Martin P. Ongol $^{3}$ \\ ${ }^{1}$ Department of Technology Acquisition, Transfer and Commercialization, National Industrial Research and \\ Development Agency, Kigali, Rwanda \\ ${ }^{2}$ Department of Applied Research and Development and Foresight Incubation, National Industrial Research and \\ Development Agency, Kigali, Rwanda \\ ${ }^{3}$ Uganda National Council for Science and Technology, Kampala, Uganda \\ Correspondence: Grace Irakiza, Department of Technology Acquisition, Transfer and Commercialization, \\ National Industrial Research and Development Agency, P.O. BOX 273, Kigali, Rwanda. Tel: 250-781-531-272. \\ E-mail: graceirakiza@gmail.com
}

Received: September 2, 2020

Accepted: December 21, 2020

Online Published: February 12, 2021

doi:10.5539/jfr.v10n2p1

URL: https://doi.org/10.5539/jfr.v10n2p1

\begin{abstract}
Although the Rwandan competent authorities are putting effort to improve the safety of traditional banana alcoholic beverages, safety problems still exist. This study aimed to apply customized diagnostic tool to gain an insight into the performance of food safety in traditional banana alcoholic beverage factories as an evidence based to support the selection of suitable interventions for improvement to assure sustainability and meet growing market of traditional banana alcoholic beverages. Literature search was used to identify context factors, quality assurance and control activities that can influence safety of banana alcoholic beverage products and validated by processors through interview and participant observation. The data were collected in eleven factories located in Kigali city and four provinces of Rwanda using an assessment tool. Data analysis was performed using Microsoft Office Excel. All factories have shown to operate in relatively high risk context (score 2-3), most of control activities were at basic level (score 1), whereas assurance activities were at relatively average level (score 1-2) which resulted into poor food safety performance (score 1). This shows that, the modern food safety practices can't be applied in traditional food processing factories due to traditional methods and equipment, low level of science-based knowledge related to processing technology, food safety and hygiene. Therefore, there is a need to design modern equipment that are easy to clean and disinfect to replace traditional ones, to train technical staff on processing technology, safety and hygiene, and to change behaviors towards making decisions based on scientific knowledge.
\end{abstract}

Keywords: diagnostic tool, food safety performance, quality assurance, quality control, traditional banana alcoholic beverage, urwagwa

\section{Introduction}

Bananas are the second most important staple and cash crop in Rwanda after beans, $80 \%$ of Rwandan households are involved in banana cultivation (National Institute of Statistics of Rwanda [NISR], 2019). The commonly grown varieties used in banana beverage production are Injagi, Fhia 17 and Fhia 25, Gros Michel, and Poyo, Mpologoma, Icyerwa, Kamaramasenge, Barabeshya, Nkazikamwa and Intokatoke. The proportions of banana types are $45 \%, 45 \%$ and $10 \%$ for brewing, cooking and dessert respectively (NISR, 2019). In Rwanda, the most commercially viable way in which banana is consumed is in the form of Banana Based Alcoholic Beverage (BBAB) and banana beer (urwagwa). BBAB is an alcoholic beverage derived from the fermentation of ripe banana pulp or banana juice obtained by any method and other safe agriculture products (Rwanda Standard Board [RSB], 2019a) whereas urwagwa is an alcoholic beverage derived from the fermentation of banana juice where sorghum grit has been added with or without honey and water (Rwanda Standard Board [RSB], 2019b). Due to high commercial prospects, BBAB and urwagwa fermentation has attracted investments in setting up, modernization, quality improvement and scaling up of production facilities. Investments in banana beverage fermentation sector have also grown with an average investment of almost 500 million Rwandan francs invested annually by the 24 enterprises since 2013 growing at $7 \%$ every year. In addition, the number of employees in 
factories have increased i.e. the factory with highest number of employees has increased from 58 to 350 employees in 2014 and 2018 respectively (National Industrial Research and Development Agency [NIRDA], 2019).

However, due to problems of poor processing technologies, use of untreated water, wild yeast, unhygienic handling activities and poor personal hygiene (Shanel \& Matemu, 2015) BBAB and urwagwa products are still contaminated by pathogens (e.g. E. coli, Staphylococcus aureus, and total coliforms) (Shale, Mukamugema, Lues, \& Venter, 2014) and Bacillus cereus (S. Kim, N. Kim, Lee, Hwang, \& Rhee, 2014). The microbial contamination may lead to unsafe products, illness, mortality and limit the products on local, regional and international markets, lower market value, reduced employment and livelihood, negative impact on non-food sectors (such as tourism) (Food and Agriculture Organization [FAO], 2017). Moreover, unavailability of literature on traditional banana alcoholic beverages, particularly regarding safety is a major constraint against industrial production in Rwanda. It is, therefore, important that processors and other stakeholders implement proper hygiene and food safety controls throughout the BBAB and urwagwa processing towards more competitive and sustainable production to satisfy markets with safe traditional products.

The government of Rwanda through Rwanda Standard Board (RSB) and Rwanda Food and Drug Administration (FDA) is putting a lot of emphases on adoption of quality assurance guidelines and standards, such as Good Manufacturing Practices (GMP), Hazard Analysis Critical Control Point (HACCP), General Principles of food hygiene and food safety quality management systems (ISO22000:2005). This has resulted into closure of some banana alcoholic beverage processing plants and others have improved their food safety activities and got Standardization Mark (S-Mark) which is product certificate issued by RSB (Rwanda Standard Board [RSB], 2018). Therefore, there is a need for research on safety performance of traditional banana alcoholic beverages processing factories in Rwanda in order to come out with strategies of enhancing safety.

This study used the principles of previous diagnostic tools developed by Luning, Bango, Kussaga, Rovira, \& Marcelis (2008); Luning et al. (2009); Luning et al. (2011a); Hamilton, Aurimar, \& Getulio (2018) to systematically analyze context characteristics, control and assurance activities that can influence the food safety management system output and at what level are they executed. These tools have been applied to a number of different type of food across supply chain (primary production, processing and trade). For instance, the tools were applied to the meat companies (Luning et al., 2011a), fish and dairy companies (Kussaga, Luning, Tiisekwa, \& Jacxsens, 2014; Njage, Opiyo, Wangoh, \& Wambui, 2018), fruits and vegetables (Nanyunja et al., 2015; Macheka, Spelt, Van der Vorst, \& Luning, 2017; Rajkovic et al., 2017) and edible oil manufacturer (Ren \& Luning, 2016). These tools can differentiate the actual performance of food safety activities based on the assumption of implemented minimum standard requirements (Jacxsens et al., 2011; Luning et al., 2011b). Furthermore, several studies have conducted on traditional banana beer processing techniques (Shale, Mukamugema, Lues, \& Venter, 2012), microorganisms and mycotoxins associated with traditional banana alcoholic beverages (S. Kim et al., 2014; Ikalafeng, 2008; Lues et al., 2011; Bullerman \& Bianchini, 2007; Shale, Mukamugema, Lues, \& Venter, 2012; Shale et al., 2014; Shanel \& Matemu, 2015). Nevertheless, there is no study conducted on safety performance in the traditional banana beverages sector on the adoptions and implementations of food safety and quality standards based on food safety diagnostic tools. Moreover, these tools do not consider the specific situations, where practices are often performed below the minimum requirements, which may lead to limited differentiation of the situation when these tools would be used (Ledo, Hettinga, \& Luning, 2020). Therefore, the aim of this study was to apply customized diagnostic tool to gain an insight into the performance of food safety in traditional banana alcoholic beverage factories as an evidence based to support the selection of suitable interventions for improvement to assure sustainability and meet growing market of traditional banana alcoholic beverages.

\section{Method}

\subsection{Development of Customized Diagnostic Tool}

The customized diagnostic tool was developed based on previous diagnostic tools to systematically analyse context factors, quality assurance and control activities that can influence safety of banana alcoholic beverages. The context factors and control and assurance activities were determined through a literature search covered google scholar, Scopus and web of science using key wards "food safety performance", "diagnostic tool", "quality control", "quality assurance", "traditional banana alcoholic beverage" "banana beer" and "urwagwa". The document reviewed were selected based on criteria that, the document is peer-reviewed, scientific or official report approved by Rwandan government institutions or other international recognised institutions and relevant to banana value chain, traditional processing technology and food safety management. The customized tool was 
validated by processors involved in banana beverage production and food quality management sector in Rwanda. The context factors, quality assurance and control activities were identified for each processing stage in the banana beverage processing, i.e. ripening, juice extraction, pasteurization, cooling, fermentation, filtration and filling. The screening resulted in 14 context factors, 18 and nine indicators of control and assurance activities respectively.

\subsection{Characteristics of Participating Banana Alcoholic Beverages Processing Factories}

In the present study, the customized diagnostic tool was applied in seven BBAB and four urwagwa processing factories coded (A to $\mathrm{G}$ ) and (coded $\mathrm{H}$ to $\mathrm{K}$ ) respectively, suitable for the case studies located in Kigali city, Eastern, Northern, western and Southern provinces of Rwanda. The factories were characterized according to size of factory based on number of permanent employees, the presence of guidelines such as GMP, S-Mark which is national standard, HACCP and ISO 22000 (Table 1). In each factory only one respondent was interviewed and participant observation was done. It was assumed in this study that these aforementioned criteria would give a reflection of the food safety performance of banana alcoholic beverage processing plants in Rwanda. These criteria were selected in accordance to the concept by G. Sarter \& S. Sarter (2012) who indicated that cases can be chosen according to the desired criteria (one which meets the desired criteria the most).

Table 1. Characteristics of participating factories

\begin{tabular}{lll}
\hline Characteristics & Size of factory & No. of factories \\
\hline No of employees & Micro (1-3) & 0 \\
& Small (4-30) & 9 \\
& Medium (31-100) & 2 \\
Large (101+) & 0 \\
Implementation of quality management system & & \\
GMP & & 11 \\
S-Mark & & 11 \\
HACCP & 0 \\
ISO 22000 & & 0 \\
\hline
\end{tabular}

\subsection{Criteria for Assessment of Food Safety Performance in Factories}

The face-to-face interview was conducted with the production managers of the factories followed by participant observation with the use of customized diagnostic tool composed of 41 questions derived from previous diagnostic tools (Luning et al., 2008; Luning et al., 2011b; Jacxsens et al., 2010). The detailed explanations in local language (Kinyarwanda) were provided for each question in the customized diagnostic tool to facilitate the interviewers an easier selection of the most representative situation to their factories. The tool contains a set of indicators to assess the risk level of the contextual factors, quality control, assurance activities and system performance output. For each indicator, five situations indicating levels of riskiness for context factors and performance levels of control and assurance activities were given (Luning et al., 2008; Luning et al., 2009; Luning et al., 2011a; Luning et al., 2011b; Luning et al., 2015) (Table 2).

Table 2. The assigned scores to overall indication of risk levels of food safety performance

\begin{tabular}{lllll}
\hline Mean scores & Assigned scores & \multicolumn{2}{l}{ Level of riskiness for decision-making } & \\
\cline { 3 - 5 } & & Context factors & $\begin{array}{l}\text { Control and } \\
\text { assurance activities }\end{array}$ & Safety output \\
\hline $0-1.2$ & 1 & Low risk & Basic level & Poor performance \\
$1.3-1.7$ & $1-2$ & Relatively moderate & Relatively average & Relatively moderate \\
$1.8-2.2$ & 2 & Moderate risk & Average level & Moderate performance \\
$2.3-2.7$ & $2-3$ & Relatively high & Relatively advanced & Relatively good \\
$2.8-3.0$ & 3 & High risk & Advanced level & Good performance \\
\hline
\end{tabular}

\subsection{Data Processing and Analysis}

Data processing was performed using Microsoft Office Excel. An independent T-test was performed to compare the mean scores of quality control and assurance activity levels, context riskiness, and food safety performance between the $\mathrm{BBAB}$ and urwagwa factories. The statistical significance was established at $\mathrm{P} \leq 0.05$. The overall mean scores were calculated and transformed to assigned overall scores in order to obtain an indication about riskiness of context factors, levels of control and assurance activities, and system output (Table 2). 


\section{Results}

For context factors, all parameters evaluated showed that there was no significant different $(\mathrm{P} \geq 0.05)$ between $\mathrm{BBAB}$ and urwagwa factories and factories operated in moderate (score 2) and relatively high risk (score 2-3) with mean score of 2.2 and 2.3 respectively (Table 3). For instance, raw materials (i.e. banana juice or pulp, sorghum flour, potable water, honey and sugar) scored as low risk factor (score 1) during processing of banana alcoholic beverage products. Though, production system such as banana juice clarification, hygienic equipment, temperature in fermentation room, technical staff, supplier relationship, inspection by food safety authorities and stakeholder's requirements were scored as high risk factors (score 3 ). For quality control activities, BBAB and urwagwa factories have shown to operate at basic level of control activities (score 1) with mean scores of 0.4 and 0.5 with exception of preventive measure such as degree of equipment maintenance and calibration program that showed significant different $(\mathrm{P} \leq 0.05)$ between $\mathrm{BBAB}$ and urwagwa factories (Table 4). The rest of the indicators of control activities were no significant different $(\mathrm{P} \geq 0.05)$ between $\mathrm{BBAB}$ and urwagwa factorie.

Table 3. Mean scores of identified context factors and risk level of factories

\begin{tabular}{|c|c|c|c|c|c|c|c|c|c|c|c|c|c|c|}
\hline \multirow[t]{3}{*}{ Context factors } & \multicolumn{14}{|c|}{ Risk level of factory } \\
\hline & \multicolumn{8}{|c|}{ Banana wine factories } & \multicolumn{5}{|c|}{ Urwagwa factories } & \multirow{2}{*}{$\frac{\text { T-test }}{\text { P-value* }}$} \\
\hline & $\mathrm{A}^{\dagger}$ & B & $\mathrm{C}$ & $\mathrm{D}$ & $\mathrm{E}$ & $\mathrm{F}$ & G & $\begin{array}{l}\text { Mean } \\
\text { scores }^{\ddagger}\end{array}$ & $\mathrm{H}$ & I & $\mathrm{J}$ & $\mathrm{K}$ & $\begin{array}{l}\text { Mean } \\
\text { score }^{\ddagger}\end{array}$ & \\
\hline Sorghum flour contamination & 1 & 1 & 1 & 1 & 1 & 1 & 1 & $1(1)$ & 1 & 1 & 1 & 1 & $1(1)$ & $1^{\mathrm{a}}$ \\
\hline Final product contamination & 1 & 2 & 1 & 2 & 2 & 1 & 2 & $1.6(1-2)$ & 1 & 3 & 2 & 2 & $2(2)$ & $0.334^{\mathrm{a}}$ \\
\hline Banana juice clarification & 2 & 3 & 3 & 3 & 3 & 3 & 3 & $2.9(3)$ & 2 & 3 & 3 & 3 & $2,8(3)$ & $0.363^{\mathrm{a}}$ \\
\hline Availability of hygienic equipment & 1 & 3 & 3 & 3 & 3 & 1 & 3 & $2.4(2-3)$ & 3 & 3 & 3 & 3 & $3(3)$ & $0.075^{\mathrm{a}}$ \\
\hline Temperature in fermentation room & 2 & 3 & 3 & 3 & 3 & 2 & 3 & $2.9(2-3)$ & 3 & 3 & 3 & 3 & $3(3)$ & $0.172^{\mathrm{a}}$ \\
\hline Presence of technical staff & 3 & 3 & 3 & 3 & 3 & 3 & 3 & $3(3)$ & 3 & 3 & 3 & 3 & $3(3)$ & $1^{\mathrm{a}}$ \\
\hline Extent of food safety leadership & 1 & 2 & 2 & 2 & 2 & 1 & 2 & $1.7(1-2)$ & 2 & 2 & 2 & 2 & $2(2)$ & $0.172^{\mathrm{a}}$ \\
\hline Sufficient of supporting information & 1 & 3 & 1 & 3 & 3 & 1 & 3 & $2.1(2)$ & 1 & 3 & 3 & 3 & $2,5(2-3)$ & $0.596^{\mathrm{a}}$ \\
\hline Level of power in supplier relationship & 3 & 3 & 3 & 3 & 3 & 3 & 3 & $3(3)$ & 3 & 3 & 3 & 3 & $3(3)$ & $1^{\mathrm{a}}$ \\
\hline Inspections by FS Authorities & 3 & 3 & 3 & 3 & 3 & 3 & 3 & $3(3)$ & 3 & 3 & 3 & 3 & $3(3)$ & $1^{\mathrm{a}}$ \\
\hline Severity of stakeholder requirement & 3 & 3 & 3 & 3 & 3 & 3 & 3 & $3(3)$ & 3 & 3 & 3 & 3 & $3(3)$ & $1^{\mathrm{a}}$ \\
\hline Extent of communication & 1 & 2 & 2 & 2 & 2 & 2 & 2 & $1.9(2)$ & 2 & 2 & 2 & 2 & $2(2)$ & $0.356^{\mathrm{a}}$ \\
\hline Degree of motivation to the workers & 2 & 2 & 2 & 2 & 2 & 2 & 2 & $2(2)$ & 2 & 2 & 2 & 2 & $2(2)$ & $1^{\mathrm{a}}$ \\
\hline Overall mean scores & $\begin{array}{l}1.7 \\
(1-2)\end{array}$ & $\begin{array}{l}2.5 \\
(2-3)\end{array}$ & $\begin{array}{l}2.2 \\
(2)\end{array}$ & $\begin{array}{l}2.5 \\
(2-3)\end{array}$ & $\begin{array}{l}2.5 \\
(2-3)\end{array}$ & $\begin{array}{l}2 \\
(2)\end{array}$ & $\begin{array}{l}2.5 \\
(2-3)\end{array}$ & $2.2(2)$ & $\begin{array}{l}2 \\
(2)\end{array}$ & $\begin{array}{l}2.5 \\
(2-3)\end{array}$ & $\begin{array}{l}2.4 \\
(2-3)\end{array}$ & $\begin{array}{l}2.4 \\
(2-3)\end{array}$ & $\begin{array}{l}2.3 \\
(\mathbf{2 - 3})\end{array}$ & $0.752^{\mathrm{a}}$ \\
\hline
\end{tabular}

${ }^{\dagger}$ Letter A, B, C, D, E, F and G denote BBAB factories while H, I, J and K denote urwagwa factories that have been evaluated. ${ }^{\dagger}$ Mean scores and correspondent scores in bracket were ranked on a scale of 1 (low risk) to 3 (high risk) devoting risk level of context factors. *P-Value with same superscript letters were not significantly different at $P \geq 0.05$. 
Table 4. Number of companies per score and statistical analysis of mean scores of control activities

\begin{tabular}{|c|c|c|c|c|c|c|c|c|c|c|c|c|c|c|}
\hline \multirow[t]{2}{*}{ Description of control activities } & \multicolumn{7}{|c|}{ BBAB factory } & \multicolumn{6}{|c|}{ Urwagwa factory } & \multirow{2}{*}{$\frac{\text { T-test }}{\text { P-value* }}$} \\
\hline & $\mathrm{A}^{\dagger}$ & $\mathrm{B}$ & $\mathrm{C}$ & $\mathrm{D}$ & $\mathrm{E}$ & $\mathrm{F}$ & $\mathrm{G}$ & $\begin{array}{l}\text { Mean } \\
\text { Scores }\end{array}$ & $\mathrm{H}$ & I & $\mathrm{J}$ & $\mathrm{K}$ & $\begin{array}{l}\text { Mean } \\
\text { Scores }^{\ddagger}\end{array}$ & \\
\hline $\begin{array}{l}\text { Degree of equipment maintenance } \\
\text { and calibration program }\end{array}$ & 1 & 0 & 1 & 0 & 0 & 1 & 0 & $0.4(1)$ & 2 & 1 & 1 & 2 & $1.5(1-2)$ & $0.023^{\mathrm{b}}$ \\
\hline $\begin{array}{l}\text { Degree of in-come raw material } \\
\text { and ingredients control }\end{array}$ & 1 & 0 & 0 & 0 & 0 & 0 & 0 & $0.1(1)$ & 0 & 0 & 1 & 0 & $0.3(1)$ & $0.725^{\mathrm{a}}$ \\
\hline $\begin{array}{l}\text { Sophistication of hygienic design of } \\
\text { equipment and facility }\end{array}$ & 1 & 0 & 2 & 0 & 0 & 1 & 0 & $0.5(1)$ & 2 & 0 & 1 & 1 & $1(1)$ & $0.428^{\mathrm{a}}$ \\
\hline Extent of supplier control & 1 & 0 & 2 & 0 & 0 & 0 & 0 & $0.4(1)$ & 2 & 0 & 1 & 1 & $1(1)$ & $0.3^{\mathrm{a}}$ \\
\hline Adequacy of sanitation program & 1 & 0 & 1 & 0 & 0 & 1 & 0 & $0.4(1)$ & 1 & 0 & 0 & 1 & $0.5(1)$ & $0.846^{\mathrm{a}}$ \\
\hline Extent of personal hygiene requirement & 2 & 1 & 2 & 0 & 1 & 2 & 1 & $1.3(1-2)$ & 2 & 0 & 2 & 2 & $1.5(1-2)$ & $0.725^{\mathrm{a}}$ \\
\hline Adequacy of physical intervention equipment & 2 & 0 & 1 & 0 & 0 & 1 & 0 & $0.6(1)$ & 1 & 0 & 1 & 1 & $0.8(1)$ & $0.657^{\mathrm{a}}$ \\
\hline Adequacy of packaging intervention & 2 & 0 & 1 & 0 & 0 & 0 & 0 & $0.4(1)$ & 1 & 0 & 0 & 0 & $0.3(1)$ & $0.657^{\mathrm{a}}$ \\
\hline Adequacy of chemical intervention methods & 2 & 0 & 1 & 0 & 0 & 0 & 0 & $0.4(1)$ & 1 & 0 & 0 & 0 & $0.6(1)$ & $0.657^{\mathrm{a}}$ \\
\hline Appropriateness of CCP analysis & 1 & 0 & 1 & 0 & 0 & 1 & 0 & $0.4(1)$ & 1 & 0 & 0 & 1 & $0.5(1)$ & $0.846^{\mathrm{a}}$ \\
\hline Adequacy measuring equipment to monitor $\mathrm{CP}$ & 2 & 0 & 1 & 0 & 0 & 0 & 0 & $0.4(1)$ & 1 & 0 & 0 & 0 & $0.3(1)$ & $0.867^{\mathrm{a}}$ \\
\hline Extent of corrective actions & 2 & 0 & 2 & 0 & 0 & 1 & 0 & $0.7(1)$ & 2 & 0 & 0 & 1 & $0.8(1)$ & $0.954^{\mathrm{a}}$ \\
\hline Limits and tolerances assessment & 2 & 0 & 2 & 0 & 0 & 0 & 0 & $0.6(1)$ & 0 & 0 & 0 & 0 & $0(1)$ & $0.172^{\mathrm{a}}$ \\
\hline Specificity of sampling plan & 0 & 0 & 0 & 0 & 0 & 0 & 0 & $0(1)$ & 1 & 0 & 0 & 0 & $0.3(1)$ & $0.391^{\text {a }}$ \\
\hline Availability of procedures & 2 & 1 & 2 & 1 & 1 & 1 & 1 & $1.3(1)$ & 0 & 1 & 1 & 2 & $1(1)$ & $0.556^{\mathrm{a}}$ \\
\hline Actual compliance to procedures & 1 & 0 & 1 & 0 & 0 & 0 & 0 & $0.3(1)$ & 0 & 0 & 0 & 1 & $0.3(1)$ & $0.912^{\mathrm{a}}$ \\
\hline Actual processing equipment capacity & 0 & 0 & 0 & 0 & 0 & 0 & 0 & $0(1)$ & 0 & 0 & 0 & 0 & $0(1)$ & $1^{\mathrm{a}}$ \\
\hline Actual analytical equipment performance & 1 & 0 & 0 & 0 & 0 & 0 & 0 & $0.1(1)$ & 0 & 0 & 0 & 0 & $0(1)$ & $0.356^{\mathrm{a}}$ \\
\hline Overall mean scores & 1.4 & 0.1 & 1 & 0 & 0.1 & 0.4 & 0.1 & $0.4(1)$ & 0.8 & 0.1 & 0.4 & 0.7 & $0.5(1)$ & $0.831^{\mathrm{a}}$ \\
\hline & (1) & (1) & (1) & (1) & (1) & (1) & (1) & & (1) & (1) & (1) & (1) & & \\
\hline
\end{tabular}

$\dagger$ Letter A, B, C, D, E, F and G denote BBAB factories while H, I, J and K denote urwagwa factories that have been evaluated. ‡Mean scores and correspondent scores in bracket were ranked on a scale of 0 (low level of performance) to 3 (Advanced level of performance). *P-Value with same superscript letters were not significantly different at $\mathrm{P} \geq 0.05$.

Few factories shown to operate at moderate level (score 2) in relation to maintenance and calibration program and personal hygiene requirements. The rest of control activities were operating at low level.

For assurance activities, overall results have shown that BBAB and urwagwa factories operate at basic (score 1) and relatively average (1-2) levels with mean scores of 0.7 and 1.3 respectively and there was no significant different $(P \geq 0,05)$ (Table 5). Only four factories have shown to operate at relatively moderate (score 1-2) level. Furthermore, few factories have shown to operate at moderate level (score 2) in relation to the use of feedback information to modify assurance activities, equipment methods and related performance, and documentation. For safety performance output, the context factors, control and assurance activities affected the food safety output of the factories leading to poor performance (score 1) with mean scores of 0.6 and 0.8 respectively (Table 6 ).

Table 5. Number of companies per score and statistical analysis of mean scores of assurance activities

\begin{tabular}{|c|c|c|c|c|c|c|c|c|c|c|c|c|c|c|}
\hline \multirow[t]{3}{*}{ Description of assurance activities } & \multicolumn{14}{|c|}{ Food safety activity level of factories } \\
\hline & \multicolumn{8}{|c|}{ BBAB factory } & \multicolumn{5}{|c|}{ Urwagwa factory } & \multirow{2}{*}{$\begin{array}{l}\text { T-test } \\
\text { P-value } \\
*\end{array}$} \\
\hline & $\mathrm{A} \dagger$ & B & $\mathrm{C}$ & $\mathrm{D}$ & $\mathrm{E}$ & $\mathrm{F}$ & G & $\begin{array}{l}\text { Mean } \\
\text { Score }^{\ddagger}\end{array}$ & $\mathrm{H}$ & I & $\mathrm{J}$ & $\mathrm{K}$ & $\begin{array}{l}\text { Mean } \\
\text { Score }^{\ddagger}\end{array}$ & \\
\hline Translating external requirement & 1 & 0 & 1 & 0 & 1 & 1 & 1 & $0,7(1)$ & 1 & 1 & 1 & 1 & $1(1)$ & $0.172^{\mathrm{a}}$ \\
\hline $\begin{array}{l}\text { Use of feedback information to } \\
\text { modify assurance activities }\end{array}$ & 2 & 0 & 2 & 0 & 0 & 2 & 1 & $1(1)$ & 2 & 1 & 1 & 2 & $1,5(1-2)$ & $0.321^{\mathrm{a}}$ \\
\hline Extent of validating preventive measures & 1 & 0 & 1 & 0 & 0 & 0 & 0 & $0,3(1)$ & 1 & 0 & 0 & 0 & $0,3(1)$ & $0.912^{\mathrm{a}}$ \\
\hline Extent of validating intervention processes & 1 & 0 & 1 & 0 & 0 & 0 & 0 & $0,3(1)$ & 1 & 0 & 0 & 0 & $0,3(1)$ & $0.912^{\mathrm{a}}$ \\
\hline Extent of validating monitoring system & 1 & 0 & 1 & 0 & 0 & 0 & 0 & $0,3(1)$ & 1 & 0 & 0 & 0 & $0,3(1)$ & $0.912^{\mathrm{a}}$ \\
\hline Verification of people related performance & 2 & 0 & 1 & 0 & 0 & 1 & 0 & $0,6(1)$ & 1 & 0 & 0 & 1 & $0,5(1)$ & $0.763^{\mathrm{a}}$ \\
\hline $\begin{array}{l}\text { Equipment and methods } \\
\text { related performance }\end{array}$ & 2 & 0 & 2 & 0 & 0 & 1 & 0 & $0,7(1)$ & 2 & 0 & 0 & 1 & $0,8(1)$ & $0.954^{\mathrm{a}}$ \\
\hline Availability of documentation & 3 & 1 & 2 & 1 & 1 & 2 & 1 & $1,6(1-2)$ & 2 & 1 & 1 & 2 & $1,5(1-2)$ & $0.867^{\mathrm{a}}$ \\
\hline Availability of record-keeping & 1 & 0 & 1 & 0 & 0 & 1 & 1 & $0,6(1)$ & 1 & 0 & 0 & 1 & $0,5(1)$ & $0.846^{\mathrm{a}}$ \\
\hline Mean scores & $\begin{array}{l}1,6 \\
(1-2 \\
)\end{array}$ & $\begin{array}{l}0, \\
1 \\
(1)\end{array}$ & $\begin{array}{l}1,3 \\
(1-2 \\
)^{2}\end{array}$ & $\begin{array}{l}0, \\
1 \\
(1)\end{array}$ & $\begin{array}{l}0, \\
2 \\
(1)\end{array}$ & $\begin{array}{l}0, \\
9 \\
(1)\end{array}$ & $\begin{array}{l}0, \\
4 \\
(1)\end{array}$ & $0,7(\mathbf{1})$ & $\begin{array}{l}1,3 \\
(1-2 \\
)\end{array}$ & $\begin{array}{l}0, \\
3 \\
(1)\end{array}$ & $\begin{array}{l}0, \\
3 \\
(1)\end{array}$ & $\begin{array}{l}0, \\
8 \\
(1)\end{array}$ & $(1,31-2)$ & $0.761^{\mathrm{a}}$ \\
\hline
\end{tabular}

$\dagger$ Letter A, B, C, D, E, F and G denote BBAB factories while H, I, J and K denote urwagwa factories that have been evaluated. $¥$ Mean scores and correspondent scores in bracket were ranked on a scale of 0 (low level of performance) to 3 (Advanced level of performance). *P-Value 
with same superscript letters were not significantly different at $\mathrm{P} \geq 0.05$.

Table 6. Overall mean scores of food safety performance indicators of all surveyed factories

\begin{tabular}{lll}
\hline Food safety output & \multicolumn{2}{l}{ Overall scores of factories } \\
\cline { 2 - 3 } & BBAB & Urwagwa \\
\hline Factors & 2.2 & 2.3 \\
Control activities & 0.4 & 0.5 \\
Assurance activities & 0.7 & 1.3 \\
Overall mean scores & $\mathbf{0 . 6}(\mathbf{1})$ & $\mathbf{0 . 8}(\mathbf{1})$ \\
\hline
\end{tabular}

\section{Discussion}

In the present study, context factors shown to operate in moderate to relatively high risk. This result implies that there was possibility of contamination, growth and survival of pathogens, restricted conditions to appropriate decision-making in food safety performance and high dependability on other chain actors resulting into a more vulnerable decision-making situation (Luning et al., 2011a; Luning et al., 2011b). For instance, even if BBAB and urwagwa are traditional fermented products with $\mathrm{pH}$ of 3.5 to 5, ethyl Alcohol content which is $16 \%$ and 3 to $15 \%$ (RSB 2019a; RSB 2019b) respectively, there is a potential susceptive to growth and survival of pathogens such as E.coli. The banana alcoholic beverage has been produced in traditional way with traditional equipment such as pit "urwina" for ripening, a wooden bowl called "umuvure" for juice extraction, pot for fermentation till 2012 when the government of Rwanda under RSB introduced food safety practices. The intension of introducing food safety practices was to produce safe and commercialized traditional products. Therefore, the processors are trying to set up a modern process. However, the processing is still done under traditional condition with inappropriate equipment such as locally made machines used with spear grasses called "inshinge" to extract juice from banana fruits, big saucepans for pasteurization and plastic barrel for fermentation which are plastic containers). Untreated water is added to juice prior to filtration. During processing, physical intervention methods (such as heating, fermentation and additional of anti-microbial agents) are applied. However, the final products still contain a high number of microbial hazards. This is because their intervention methods were not supported by scientific information and expert knowledge, and the processors are still operating in traditional way. The production capacity of the equipment is not known, no specifications and not tested for $\mathrm{BBAB}$ and urwagwa making. Compared to other factors, raw materials (i.e. banana juice or pulp, sorghum flour, water, honey and sugar) was scored as low risk with low possibility of contamination, growth and/or survival of microorganisms. This is contrary to the study of Nkwe, Taylor, \& Siame (2005) who found that raw materials and ingredients used in beer brewing activity, such as cereal grains and fruits are vulnerable to fungal infestation in field, storage and/or during malting stages. In most of the factories, safety of packaging material was scored as high risk. This is because packaging materials used for BBAB and urwagwa were plastic, glass bottles and jelly cans that have been used for other purpose. These packaging materials were collected from different locations and washed to be used for packing banana beverage products. Moreover, the factories did not have proper cleaning facilities for the bottles and validation of effectiveness of cleaning and disinfection was not performed. All factories surveyed were operating manually and there was clear interference of personnel, processing environment was characterized by poor hygiene with no clear zoning to prevent cross-contamination. The plants layout did not facilitate proper flow of materials, people and wastes. All factories shown high variability in their product characteristics and there was no innovative products (line) from 2010 the time factories have started operating. Furthermore, all factories have shown restricted condition to appropriate decision-making in food safety performance. This was shown by insufficiency of operator's competence due to low level of education for employees and inadequate training programs for food safety. In each factory, only one person was responsible for all activities related to quality assurance, quality control, production monitoring with no specific food safety expertise. The expertise is hired from outside the factories (i.e. GMP and HACCP consultants). However, the factories have collaboration with National Industrial Research and Development Agency (NIRDA) and RSB to support them in food safety improvement. They have shown inadequate hazard analysis, absence of Critical Control Points (CCP) allocation and the absence of laboratory facilities. All microbial analyses are done at RSB laboratory. In previous study conducted by Luning et al. (2011b) found that lack of technical staff and absence of laboratory facilities affect negatively a good performance of food safety. The majority of factories have shown limited financial and human resources to create helpful organizational conditions resulting in lower investments in appropriate hygienic equipment and buildings, and hiring qualified 
workers. This affects priorities in food safety and quality management decisions and implementation of quality assurance standards/guidelines like HACCP and ISO 22000. This is similar to the study of Jevšnik, Hlebec, \& Raspor (2008) who found that appropriate competences and experience of food operators are crucial for effective control of food safety and quality. In addition, there was no detailed written vision statement on safety, the information related to food safety management were not updated and not accessible for the workers, only the owner of the factory accesses the information. Moreover, there was no evidence that they conduct regular meetings related to food safety. According to Holt \& Henson (2000) formal communication is very important in order to avoid guesswork. Only three BBAB and one urwagwa factories have shown that are operating in low risk where the information system was centralized, accurate, updated and easily available to the workers.

For the control activities, all factories were operating at basic level. This result implies that the factories were using their own experience, general knowledge, unstable, incomplete methods or programmes and not standardized equipment (Luning et al., 2008). It was found, there was incomplete sanitation program, there was no clear indicator that the cleaning agents (detergents and disinfectants) were tested on their effectiveness for banana alcoholic beverage processing factory. The pests (like flies, cockroaches and rats), dirty and broken floors, walls, and ceilings were observed in the production areas. Banana alcoholic beverage factories should re-design their factories and equipment, develop specific sanitation programmes (such as equipment, processing zones, surrounding environment) and introduce strict personnel hygiene requirements. It was found that the maintenance and calibration of equipment is done only in case there is a problem. This affected the adequacy of intervention equipment. The studies conducted by Luning, Marcelis, \& Ongen (2002) found that the adequacy of intervention equipment is affected by how well potential process capability and the maintenance and calibration program suit the specific food processing situation. The factories did not check process temperatures and times (such as heating, cooling and during fermentation period); no monitoring compliance with sanitation and disinfection requirements such as contact times, disinfectant strengths and temperatures. None of them is implementing HACCP principles or other quality assurance standards. It was found that all factories conducted microbial analysis such as Escherichia coli, Total viable count, Salmonella ssp., Staphylococcus aureus, lactic Acid Bacteria and moulds at the accredited laboratory in RSB. However, microbiological analysis was conducted for the purpose of product certification known as S-Mark. Various studies proved that inadequacies in monitoring systems can cause safety problems, such as inappropriate selection and risk evaluation of hazards, inappropriate allocation of CCPs, inadequate sampling design (Panisello \& Quantick, 2001), inadequate monitoring equipment, poor equipment calibration, and inappropriately described corrective actions (Escriche, Doménech, \& Baert, 2006). Only RSB which is national competent authority inspects the factories for their compliance in Good Hygiene Practice, GMP and other standards set by RSB which explains the low scores of surveyed factories. The judgement criteria are done based on combination of legal criteria and requirements and/or specifications set by RSB only. According to Jacxsens et al. (2010), involvement of accredited third parties such as private audits in food safety audits could enable intensive assessment of food safety performance. This can provide an independent judgement on the performance of current systems (Hatanaka, Bain, \& Busch, 2005). Kussaga, Luning, Jacxsens, \& Tiisekwa (2013) found that if a factory lacks complaint registration procedures, may also lack adequate information to evaluate performance of their systems. The procedures were partially available in the factories and not kept-up-to date. These procedures are also difficult to understand by the workers because of lack of proper training on food safety and some documents are written in English. The majority of factories showed incomplete description of corrective actions based on experience and there was no analysis of cause of deviation in case of non-conformity. For all factories, the hygienic performance equipment and facilities was a concern since they knew the importance of using hygienic design equipment and facilities. However, their equipment's were not easy to clean and to disinfect, not easy to dismantle, unstable performance, presence of dead areas that can increase the chance of microbial contamination.

The assurance activities of the factories such as record-keeping and documentation, validation of interventions, verification of procedures and compliance are not performed well. There was no evidence that the factories validate the effectiveness of their control activities. Moreover, the verification of an implemented quality control and assurance activities was at basic level. This was because some factories had low performance of measuring equipment and analytical equipment. For documentation and record-keeping, all factories did not operate in-process record keeping by maintaining daily processing activities. Temperature, time, ingredients, product yield, waste, rework were not documented. Since workers had no access to information from processing, they were not able to organise documentation and record keeping (Luning et al., 2015) leading to failure in validation and verification in the long-term business operation and implementation of control and assurance activities because such systems require huge amount of documentation (Carrascosa et al., 2016). Traditional banana alcoholic beverage factories were performing under relatively high risk context factors and at basic level of 
control and assurance activities leading to poor performance of safety output. This study is similar to the study of Sawe, Onyango, \& Njage (2014) who found that, the poor food safety output may be attributed to poor design and operation of assurance and control measures.

\section{Conclusion}

Even though, the processors are interested in investment in setting up, modernization, quality improvement and scaling up of production facilities in traditional banana alcoholic, it can be concluded that the performance of control and assurance activities in Rwandan banana beverage factories were of basic level resulted in poor food safety performance. This shows that, the modern food safety practices can't be applied in traditional food processing factories due to traditional methods and equipment, low level of science-based knowledge related to processing technology, food safety and hygiene. The key factors contributing to the poor performance were found to be traditional processing methods, inadequate technical staff, lack of capital resources, people behavior toward food safety, lack of safety commitment, inadequate supporting document system and poor design of control measures. Moreover, inadequate sanitation program, poor hygienic design of equipment and building, lack of CCP analysis, verification, validation, inadequate sampling plan and recording keeping were also found as contributing factors. Therefore, there is a need to design modern equipment that are easy to clean and disinfect to replace traditional ones, to train technical staff about processing technology, safety and hygiene, and to change behaviors towards making decisions based on scientific knowledge.

Due to the costs and time some interventions can be taken in phases, starting with low cost intervention measures related to managerial aspects (such as enhancement of organizational and chain characteristics, set a proper system for monitoring of processing activities, verification and validation of effectiveness of control measures, develop food safety culture system based on Rwandan context and establish a comprehensive documentation and record-keeping systems) that can be implemented in short term. Then and there, the high cost intervention measures (such as investment in hygienic design of buildings and equipment) that can be adopted for long term. This study was a first attempt to provide evidence about the food safety performance in Rwandan traditional banana brewing factories. There is therefore need in-depth studies on hygiene and sanitation and food safety culture in traditional banana processing sector. This could give insight in best practices to improve food safety output and enhance robustness of the evidence for the policy makers.

\section{Acknowledgments}

This research has been co-funded by International Foundation for Science (IFS), grant awarded to Ms. Grace Irakiza and supported by National Council for Science and Technology (NCST), Rwanda. The authors acknowledge all urwagwa processors and experts who provided the information that have been used for development of urwagwa product assessment tool. Furthermore, we acknowledge in-kind support provided by National Industrial Research and Development Agency (NIRDA) and Uganda National Council for Science and Technology (UNCST).

\section{References}

Bullerman, L. B., \& Bianchini, A. (2007). Stability of mycotoxins during food processing. International journal of food microbiology, 119(1-2), 140-146. https://doi.org/10.1016/j.ijfoodmicro200707035

Carrascosa, C., Millán, R., Saavedra, P., Jaber, J. R., Raposo, A., \& Sanjuán, E. (2016). Identification of the risk factors associated with cheese production to implement the hazard analysis and critical control points (HACCP) system on cheese farms. Journal of Dairy Science, 99(4), 2606-2616. https://doi.org/10.3168/jds.2015.10.301

Escriche, I., Doménech, E., \& Baert, K. (2006). Design and implementat on of an HACCP system. In P. A. Luning, F. Devlieghere, \& R. Verhé (Eds.), Safety in agri-food chains (pp. 303-354). Wageningen Academic: Publishers Wageningen.

Food and Agriculture Organization. (2017). Food safety risk management. Evidence informed policies and decisions, considering multiple factors. Retrieved from https://www.fao.org/food/food-safety-quality/home-page

Hamilton, P., Aurimar, F. B., \& Getulio, K. A. (2018). Critical factors of success for quality and food safety management: Classification and prioritization. Universal Journal of Industrial and Business Management, 6(2), 30-41. https://doi.org/10.13189/ujibm.2018.060202

Hatanaka, M., Bain, C., \& Busch, L. (2005). Third-party certification in the global agrifood system. Food Policy, 30(3), 354-369. https://doi.org/10.1016/j.foodpol.2005.05.006 
Holt, G., \& Henson S. (2000). Quality assurance management in small meat manufacturers. Food Control, 11(4), 319-326. https://doi.org/10.1016/S0956-7135(99)00117-6

Ikalafeng, B. K. (2008). Microbiota and mycotoxins in traditional beer of the greater Kimberley area and associated brewing and consumption practices (Doctoral dissertation). Bloemfontein, Central University of Technology, Free State.

Jacxsens, L., Luning, P., Marcelis, W., van Boekel, T., Rovira, J., Oses, S., Kousta, M., Drosinos, E., Jasson, V., \& Uyttendaelea, M. (2011). Tools for the performance assessment and improvement of food safety management systems. Trends in Food Science and Technology, 22, 80-89. https://doi.org/10.1016/j.tifs.2011.02.008

Jacxsens, L., Uyttendaele, M., Devlieghere, F., Rovira, J., Gomez, S. O., \& Luning, P. A. (2010). Food safety performance indicators to benchmark food safety output of food safety management systems. International Journal of Food Microbiology, 141, 180-187. https://doi.org/1 0.1016/j.ijfoodmicro.2010.05.003

Jevšnik, M., Hlebec, V., \& Raspor, P. (2008). Food safety knowledge and practices among food handlers in Slovenia. Food Control, 19(12), 1107-1118. https://doi.org/10.1016/j.foodcont.2007.11.010

Kim, S. A., Kim, N. H., Lee, S. H., Hwang, I. G., \& Rhee, M. S. (2014). Survival of foodborne pathogenic bacteria (Bacillus cereus, Escherichia coli O157: H7, Salmonella enterica serovar Typhimurium, Staphylococcus aureus, and Listeria monocytogenes) and Bacillus cereus spores in fermented alcoholic beverages (beer and refined rice wine). Journal of Food Protection, 77(3), 419-426. https://doi.org/10.4315/0362-028X.JFP-13-234

Kussaga, J. B., Luning, P. A., Jacxsens, L., \& Tiisekwa, B. P. M. (2013). Diagnosis of food safety management systems performance in food processing sectors for export and domestic markets. African Journal of Food Science and Technology, 4(10), 240-250.

Kussaga, J. B., Luning, P. A., Tiisekwa, B. P., \& Jacxsens, L. (2014). Challenges in performance of food safety management systems: A case of fish processing companies in Tanzania. Journal of Food Protection, 77(4), 621-630. https://doi.org/10.4315/0362-028X.JFP-13-254

Ledo, J., Hettinga, K. A., \& Luning, P. A. (2020). A customized assessment tool to differentiate safety and hygiene control practices in emerging dairy chains. Food Control, 111, 107072. https://doi.org/10.1016/j.foodcont.2019.107072

Lues, J. F. R., Ikalafeng, B. K., Maharasoa, M., Shale, K., Malebo, N. J., \& Pool, E. (2011). Staphylococci and other selected microbiota associated with indigenous traditional beer. African Journal of Microbiology Research, 5, 1691-1696. https://doi.org/10.5897/AJMR11.402

Luning, P. A., Bango, L., Kussaga, J., Rovira, J., \& Marcelis, W. J. (2008). Comprehensive analysis and differentiated assessment of food safety control systems: a diagnostic instrument. Trends in Food Science and Technology, 19(10), 522-534. https://doi.org/10.1016/j.tifs.2008.03.005

Luning, P. A., Jacxsens, L., Rovira, J., Osés, S. M., Uyttendaele, M., \& Marcelis, W. J. (2011b). A concurrent diagnosis of microbiological food safety output and food safety management system performance: Cases from meat processing industries. Food Control, 22(3-4), 555-565. https://doi.org/10.1016/j.foodcont.2010.10.003

Luning, P. A., Kirezieva, K., Hagelaar, G., Rovira, J., Uyttendaele, M., \& Jacxsens, L. (2015). Performance assessment of food safety management systems in animal-based food companies in view of their context characteristics: A European study. Food Control, 49, 11-22. https://doi.org/10.1016/j.foodcont.2013.09.009

Luning, P. A., Marcelis, W. J., \& Ongen, W. M. (2002). Food quality management: a techno-managerial approach. Wageningen Pers. pp. 323.

Luning, P. A., Marcelis, W. J., Rovira, J., Van Boekel, M. A. J. S., Uyttendaele, M., \& Jacxsens. L. (2011a). A tool to diagnose context riskiness in view of food safety activities and microbiological safety output. Trends in Food Science and Technology, 22, 67-79. https://doi.org/10.1016/j.tifs.2010.09.009

Luning, P. A., Marcelis, W. J., Rovira, J., Van der Spiegel, M., Uyttendaele, M., \& Jacxsens, L. (2009). Systematic assessment of core assurance activities in a company specific food safety management system. Trends in Food Science and Technology, 20(6-7), 300-312. https://doi.org/10.1016/j.tifs.2009.03.003

Macheka, L., Spelt, E., Van der Vorst, J. G., \& Luning, P. A. (2017). Exploration of logistics and quality control activities in view of context characteristics and postharvest losses in fresh produce chains: A case study for 
tomatoes. Food Control, 77, 21-234. https://doi.org/10.1016/j.foodcont.2017.02.037

Nanyunja, J., Jacxsens, L., Kirezieva, K., Kaaya, A. N., Uyttendaele, M., \& Luning, P. A. (2015). Assessing the status of food safety management systems for fresh produce production in East Africa: evidence from certified green bean farms in Kenya and noncertified hot pepper farms in Uganda. Journal of Food Protection, 78(6), 1081-1089. https://doi.org/10.4315/0362-028X.JFP-14-364

National Industrial Research and Development Agency. (2017). Technology audit: Banana wine value chain assessment. Retrieved from https://www.nirda.gov.rw/uploads/tx_dce/NIRDA.2017._Banana_wine_value_chain_report_04.pdf

National Institute of Statistics of Rwanda. (2019). Seasonal Agricultural Survey. Retrieved from http://www.statistics.gov.rw/publication/seasonal-agricultural-survey-report-2016

Njage, P. M. K., Opiyo, B., Wangoh, J., \& Wambui, J. (2018). Scale of production and implementation of food safety programs influence the performance of current food safety management systems: Case of dairy processors. Food Control, 85, 85-97. https://doi.org/10.1016/j.foodcont.2017.09.015

Nkwe, D. O., Taylor, J. E., \& Siame, B. A. (2005). Fungi, aflatoxins, fumonisin B 1 and zearalenone contaminating sorghum-based traditional malt, wort and beer in Botswana. Mycopathologia, 160(2), 177-186. https://doi.org/10.1007/s11046-005-6867-9

Panisello, P. J., \& Quantick, P. C. (2001). Technical barriers to hazard analysis critical control point (HACCP). Food control, 12(3), 165-173. https://doi.org/10.1016/S0956-7135(00)00035-9

Rajkovic, A., Smigic, N., Djekic, I., Popovic, D., Tomic, N., Krupezevic, N., Uyttendaele, M., \& Jacxsens, L. (2017). The performance of food safety management systems in the raspberries chain. Food control, 80, 151-161. https://doi.org/10.1016/j.foodcont.2017.04.048

Ren, Y., He, Z., \& Luning, P. A. (2016). A systematic assessment of quality assurance-based food safety management system of Chinese edible oil manufacturer in view of context characteristics. Total Quality Management and Business Excellence, 27(7-8), 897-911. https://doi.org/10.1080/14783363.2016.1187995

Rwanda Standards Board. (2018). Focus on standardization in the banana and plant beverages sector. Retrieved from http://www.rsb.gov.rw/fileadmin/user_upload/files/pdf/Standards_Journal_June_2018_Issue_13.pdf

Rwanda Standards Board. (2019a). Urwagwa specification. Rwanda Standards.

Rwanda Standards Board. (2019b). Banana based Alcoholic Beverages. Rwanda Standards.

Sarter, G., \& Sarter, S. (2012). Promoting a culture of food safety to improve hygiene in small restaurants in Madagascar. Food Control, 25(1), 65-171. https://doi.org/10.1016/j.foodcont.2011.10.023

Sawe, C. T., Onyango, C. M., \& Njage, P. M. (2014). Current food safety management systems in fresh produce exporting industry are associated with lower performance due to context riskiness: Case study. Food Control, 40, 335-343. https://doi.org/10.1016/j.foodcont.2013.12.019

Shale, K., Mukamugema, J., Lues, R. J., \& Venter, P. (2012). Toxicity profile of commercially produced indigenous banana beer. Food Additives and Contaminants: Part A, 29(8), 1300-1306. https://doi.org/10.1080/19440049.2012.688879

Shale, K., Mukamugema, J., Lues, R., \& Venter, P. (2014). Possible microbial and biochemical contaminants of an indigenous banana beer 'Urwagwa': a mini review. African Journal of Food Science, 8(7), 376-389. https://doi.org/10.5897/AJFS12.134

Shanel, K., \& Matemu, A. (2015). Microbial Quality of Traditional Banana Alcoholic Beverages in Arusha, Tanzania. Food Science and Quality Management, 38, 28-38.

\section{Copyrights}

Copyright for this article is retained by the author(s), with first publication rights granted to the journal.

This is an open-access article distributed under the terms and conditions of the Creative Commons Attribution license (http://creativecommons.org/licenses/by/4.0/). 